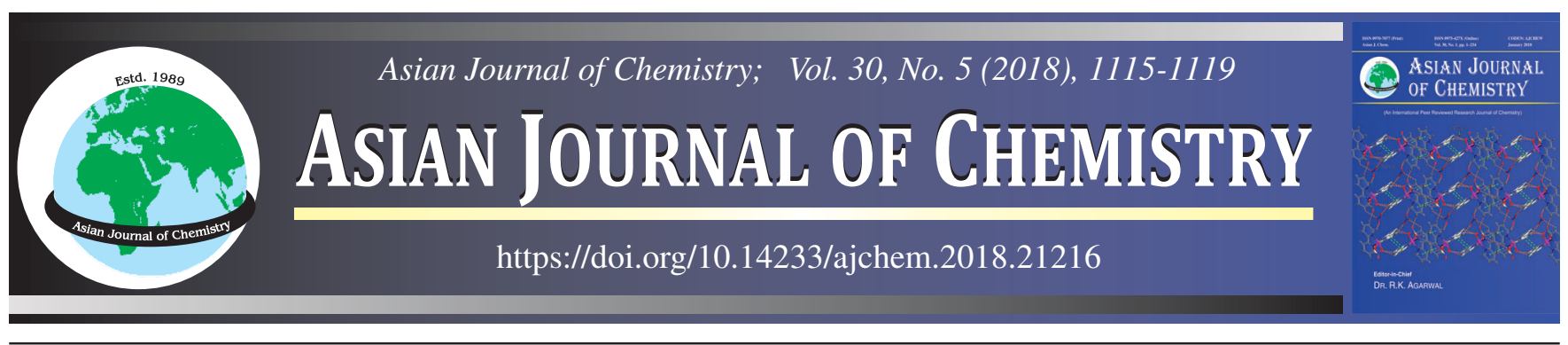

\title{
Synthesis, Characterization and Antidiabetic Activity of Some Water Soluble Zn(II) Complexes with (E)-N-(Thiophen-2-ylmethylene)anilines
}

Debabrata Paria ${ }^{1}$, Sajal Kundu $^{1, *}$, Khaidem Kennedy Singh $^{2}$, S. Sureshrumar Singh ${ }^{2}$ and Keisham Surjit Singh ${ }^{1, *}$

${ }^{1}$ Department of Chemistry, National Institute of Technology Agartala, Jirania-799 046, India

${ }^{2}$ Department of Forestry, North Eastern Regional Institute of Science and Technology, Nirjuli-791 109, India

*Corresponding authors: E-mail: kundu12@gmail.com; surjitkeisham@yahoo.co.in

Received: 8 January 2018;

Accepted: 15 February 2018;

Published online: 29 March 2018;

AJC-18851

Synthesis and spectroscopic characterization of five water soluble zinc(II) complexes of $(E)$-N-(thiophen-2-ylmethylene)anilines $\left(\mathrm{L}^{1-3}\right)$ with the general formula $\left[\mathrm{ZnX}_{2} \mathrm{~L}^{1-3} ; \mathrm{X}=\mathrm{Cl}^{-}, \mathrm{NO}_{3}^{-} ;(\mathbf{1 - 5})\right]$ are reported. The complexes were characterized by elemental analysis, UVvisible, fluorescence, IR and ${ }^{1} \mathrm{H}$ NMR spectroscopy. Efforts for getting single crystal suitable for X-ray crystal structure could not be achieved. However, from spectroscopic data, the complexes are proposed to adopt four coordinated tetrahedral and six coordinated octahedral geometry. All the complexes were obtained in moderate to good yields and these compounds behave as non-electrolytes in acetonitrile solution. UV-visible and fluorescence spectral study of complexes 1-5 indicate (intra-ligand) ligand to ligand charge transfer transition. The complexes were screened for their antidiabetic activity against $\alpha$-glucosidase enzyme and compared with standard drug acarbose. Complex 1 was found to exhibit effective antidiabetic activity among the tested compounds.

Keywords: Water soluble Zinc(II) complexes, (E)-N-(thiophen-2-ylmethylene)aniline, Antidiabetic activity.

\section{INTRODUCTION}

Schiff base complexes derived from heterocyclic compounds have been increasing area of interest in the field of chemistry $[1,2]$. Heterocyclic compounds such as pyridine, thiophene, 2,2bypyridine moiety and related molecules are considered to be good ligands due to the presence of at least one hetero atom in the ring with a localized pair of electrons. The successful formation of the complexes, has led to the formation of a series of novel compounds with a wide range of physical, chemical and biological properties $[3,4]$. In this context, thiophene moiety containing Schiff base is widely studied [5,6]. Further, metal complexes with sulfur containing unsaturated ligands are also of a great interest in inorganic and organometallic chemistry especially due to their potential novel electrical and magnetic properties [7]. Belo [8] reviewed the importance of sulphur containing ligands and coordination ability of sulphur atom and the Schiff base continue to occupy an important position as ligands in metal coordination chemistry [9]. Moreover, the Schiff base derived from 2-thiophene carboxaldehyde and 2-aminobenzoic acid and their metal complexes showed a good antibacterial activity against Escherichia coli, Pseudomonas aeruginosa and Staphylococcus pyogenes [10]. The protonation constants of Schiff base and stability constants of the complexes have also been determined potentiometrically [11] and studied their solid state conductivities [12].
Furthermore, Schiff base derived from sulfanethiadizole and salicylaldehyde or thiophene 2-carboxaldehyde and their metal complexes exhibited toxicities against various insects [13]. On the other hand, a series of $\mathrm{Cu}$ (II) complexes with mono Schiff base of dipropylene triamine with 2-thiophene carboxaldehyde, has been tested for antiinflammatory and antioxidant activity [14]. The tested compounds inhibited the carrageenininduced rat pawoedema and showed important scavenging activity. Moreover, Kirchner et. al. [15] reported palladium(II) complexes of Schiff base derived from 2-thiophene carboxaldehyde moiety. The investigated complexes were found to be active as catalysts for Suzuki coupling reactions and were compared to related dimine systems and proposed an alternative to existing catalytic systems. Furthermore, zinc(II) mononuclear complex with 3-carboxypyrazole ligand were studied for their antidiabetic activity and found to exhibit potential activity [16]. In addition, a series of copper(II) and zinc(II) complexes involving Schiff base derived from salicylaldehyde and $\beta$-alanine were also reported and the synthesised complexes have been evaluated for their antioxidant and antidiabetic activites [17].

Keeping in view of the versatile applications of metal complexes of Schiff base ligands derived from heterocyclic compounds, it was thought of worthwhile to synthesize and characterize some metal complexes of $\mathrm{Zn}$ (II) with Schiff base ligands (in situ derived from thiophene-2 carboxyaldehyde and substituted 
aniline), viz. (E)-N-(thiophen-2-ylmethylene)anilines, $(E)-4$ methyl-N-(thiophen-2-ylmethylene)aniline and (E)-4-chloro$\mathrm{N}$-(thiophen-2-ylmethylene)aniline. Interesting biological properties of these $\mathrm{N}, \mathrm{S}$ donor Schiff base complexes (having the composition $\left[\mathrm{MX}_{2} \mathrm{~L}^{1-3} ; \mathrm{X}=\mathrm{Cl}^{-}, \mathrm{NO}_{3}^{-}\right.$, has prompted us to prepare the present series of complexes which describe the antidiabetic activity against the enzyme $\alpha$-glucosidase. The ligand skeleton system used in the synthesis of zinc(II) complexes with $(E)-\mathrm{N}$-(thiophen-2-ylmethylene)aniline $\left(\mathrm{L}^{\mathrm{n}}\right)$ are shown in Fig. 1(a), while the structural motifs shown by zinc chloride and zinc nitrite are shown in Fig. 1(b). Consequently, zinc complexes 1-5 were investigated for their antidiabetic properties against $\alpha$-glucosidase enzyme.

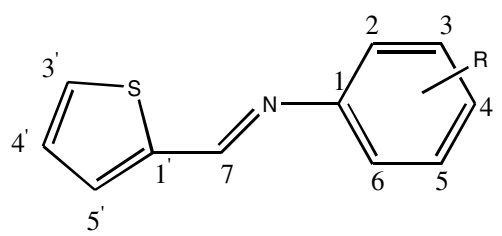

(E)-N-(thiophen-2-ylmethylene)aniline $\left(\mathrm{L}^{\mathrm{n}}\right)$

(a) $\mathrm{R}=\mathrm{H}\left(\mathrm{L}^{1}\right), 4-\mathrm{CH}_{3}\left(\mathrm{~L}^{2}\right), 4-\mathrm{Cl}\left(\mathrm{L}^{3}\right)$

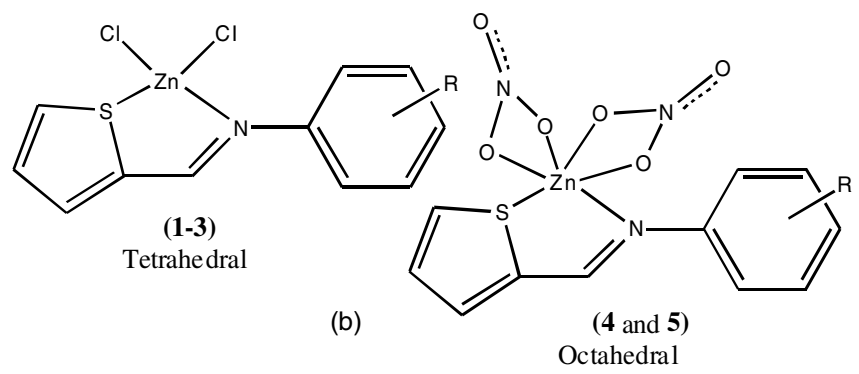

Fig. 1. Generic structure of the ligands abbreviations: (a) $L^{n}(n=1-3)$ with the numbering protocol and (b) Structural motifs of $\mathrm{Zn}(\mathrm{II}) \mathrm{Cl}_{2}$ and $\mathrm{Zn}(\mathrm{II})\left(\mathrm{NO}_{3}\right)_{2}$ compounds

\section{EXPERIMENTAL}

All the chemicals were used as purchase without purification, thiophene-2-carboxaldehyde (Merck), aniline, $\mathrm{ZnCl}_{2}$ (SD Fine), $\mathrm{Zn}\left(\mathrm{NO}_{3}\right)_{2}, p$-toluidine, $p$-chloroanline $(\mathrm{CDH})$ were used as such. Solvents were purified following standard procedures and were freshly distilled prior to use. (E)-N-(Thiophen-2ylmethylene)aniline derivatives $\mathrm{L}^{1-3}$ were prepared in situ from thiophene-2-carboxaldehyde and the corresponding anilines. Attempts to prepare crystalline (E)-N-(thiophen-2-ylmethylene)aniline were unsuccessful and in all instances either oil or a viscous liquid was isolated. Melting points were recorded in capillary tubes on a Scanca apparatus and are uncorrected. IR spectra in the range $4000-400 \mathrm{~cm}^{-1}$ were obtained using KBr pellets on a Shimadzu FT-IR-8400S spectrophotometer. The ${ }^{1} \mathrm{H}$ NMR spectra were recorded on a Bruker Avance II spectrometer and measured at $400.13 \mathrm{MHz}$. The ${ }^{1} \mathrm{H}$ chemical shifts were referenced to tetramethylsilane set at $0.00 \mathrm{ppm}$. The UV-visible spectra of the complexes were observed in UV-1800 Shimadzu spectrophotometer in acetonitrile at 200$800 \mathrm{~nm}$ range. Fluorescence spectra were obtained on a Perkin Elmer spectrofluorimeter model LS55 (with the excitation and emission slits fixed at 10 and $20 \mathrm{~nm}$, respectively) and corrected for the instrument response function. Quartz cuvettes of 10 $\mathrm{mm}$ optical path length received from Perkin Elmer, USA (part no. B0831009) and Hellma, Germany (type 111-QS) were used for measuring absorption and fluorescence spectra, respectively. Fluorescence quantum yields $\left(\phi_{\mathrm{f}}\right)$ were calculated by comparing the total fluorescence intensity under the whole fluorescence spectroscopic range with that of a standard method described elsewhere [18]. The relative experimental error of the measured quantum yield was estimated within \pm $10 \%$ solution. The electrical conductivity measurements were made using a Eutech Instruments automatic precision bridge Con510.

\section{Synthesis of zinc complexes}

Synthesis of $\left[\mathrm{ZnCl}_{2}\left(\mathbf{L}^{1}\right)\right](\mathbf{1})$ : To a solution of thiophene2-carboxaldehyde $(0.50 \mathrm{~g}, 4.45 \mathrm{mmol})$ in ethanol $(5 \mathrm{~mL})$ was added a solution of aniline $(0.415 \mathrm{~g}, 4.45 \mathrm{mmol})$ in ethanol ( 5 $\mathrm{mL}$ ). The mixture was stirred at ambient temperature for $30 \mathrm{~min}$. To this reaction mixture, $\mathrm{ZnCl}_{2}(0.607 \mathrm{~g}, 4.45 \mathrm{mmol})$ in methanol $(20 \mathrm{~mL})$ was added dropwise under stirring conditions which resulted in the immediate formation of a yellow precipitate. The stirring was continued for $3 \mathrm{~h}$ and then the mixture was filtered. The residue was washed with methanol $(3 \times 5 \mathrm{~mL})$ and dried in vacuo. The dried solid was dissolved by boiling in $50 \mathrm{~mL}$ of acetonitrile and filtered while hot. The filtrate was left for slow evaporation at room temperature affording yellow crystalline material. Complexes $\mathbf{2 - 5}$ were prepared as yellow crystals in a similar manner to that described for the preparation of complex $\mathbf{1}$, using corresponding anilines and metal salts as starting materials.

$\left[\mathbf{Z n C l}_{2}\left(\mathbf{L}^{1}\right)\right]$ (1): Yield $0.62 \mathrm{~g}(41 \%)$. m.p. $243-244^{\circ} \mathrm{C}$. Anal. calc. (\%) for $\mathrm{C}_{11} \mathrm{H}_{9} \mathrm{NSZnCl}_{2}$ : C, 40.83; H, 2.80; N, 4.33 . Found (\%): C, 40.10; H, 2.71; N, 4.18\%. $\Lambda_{\mathrm{m}}\left(\mathrm{CH}_{3} \mathrm{CN}\right): 7 \Omega^{-1}$ $\mathrm{cm}^{2} \mathrm{~mol}^{-1}$. IR $\left(\mathrm{KBr}, \mathrm{cm}^{-1}\right): 1670 \mathrm{v}_{\text {asym }}(\mathrm{C}(\mathrm{H})=\mathrm{N})$ imine; 838 $v\left(\mathrm{C}-\mathrm{S}\right.$-C)thiophene. ${ }^{1} \mathrm{H} \mathrm{NMR}\left(\mathrm{CDCl}_{3}\right): \delta 8.56(\mathrm{~s}, 1 \mathrm{H}, \mathrm{H}-7), 7.86$ (d, 1H, H-3'), 7.82 (d, 1H, H-5'), 7.40 (t, 1H, H-4'], 7.38 (d, 1H, H-2), 7.34 (d, 1H, H-6), 7.22 (t, 1H, H-3), 7.20 (t, 1H, H5), $7.08(\mathrm{t}, 1 \mathrm{H}, \mathrm{H}-4) \mathrm{ppm}$.

[ $\left.\mathbf{Z n C l}_{2}\left(\mathbf{L}^{2}\right)\right]$ (2): Yield: $0.80 \mathrm{~g}(51 \%)$. m.p. $212-215^{\circ} \mathrm{C}$. Anal. calc. (\%) for $\mathrm{C}_{12} \mathrm{H}_{11} \mathrm{NSZnCl}_{2}: \mathrm{C}, 42.69 ; \mathrm{H}, 3.28 ; \mathrm{N}, 4.15$. Found (\%): C, 42.10; H, 3.18; N, 3.98. $\Lambda_{\mathrm{m}}\left(\mathrm{CH}_{3} \mathrm{CN}\right): 6 \Omega^{-1}$ $\mathrm{cm}^{2} \mathrm{~mol}^{-1}$. IR $\left(\mathrm{KBr}, \mathrm{cm}^{-1}\right): 1659 v_{\text {asym }}(\mathrm{C}(\mathrm{H})=\mathrm{N})$ imine; 813 $v(\mathrm{C}-\mathrm{S}-\mathrm{C})$ thiophene. ${ }^{1} \mathrm{H}$ NMR $\left(\mathrm{CDCl}_{3}\right): \delta 8.56(\mathrm{~s}, 1 \mathrm{H}, \mathrm{H}-7)$, 7.49 (d, 1H, H-3'), 7.46 (d, 1H, H-5'), 7.18 [t, 1H, H-4'), 7.12 (m, 4H, H-2,3,5,6], 2.35 (s, 3H, $\left.\mathrm{CH}_{3}\right) \mathrm{ppm}$.

$\left[\mathbf{Z n C l}_{2}\left(\mathbf{L}^{3}\right)\right]$ (3): Yield $0.78 \mathrm{~g}(47 \%)$. m.p. $80-81{ }^{\circ} \mathrm{C}$. Anal. calc. (\%) for $\mathrm{C}_{11} \mathrm{H}_{8} \mathrm{NSZnCl}_{2}: \mathrm{C}, 36.91 ; \mathrm{H}, 2.25 ; \mathrm{N}, 3.91$. Found (\%): C, 37.08; H, 2.33; N, 4.05. $\Lambda_{\mathrm{m}}\left(\mathrm{CH}_{3} \mathrm{CN}\right): 8 \Omega^{-1} \mathrm{~cm}^{2} \mathrm{~mol}^{-1}$. IR $\left(\mathrm{KBr}, \mathrm{cm}^{-1}\right): 1615 \mathrm{v}_{\text {asym }}(\mathrm{C}(\mathrm{H})=\mathrm{N})$ imine; $869 \mathrm{v}(\mathrm{C}-\mathrm{S}-\mathrm{C})$ thiophene. ${ }^{1} \mathrm{H}$ NMR $\left(\mathrm{CDCl}_{3}\right): \delta 8.54(\mathrm{~s}, 1 \mathrm{H}, \mathrm{H}-7), 7.54(\mathrm{~m}$, $\left.2 \mathrm{H}, \mathrm{H}-3^{\prime}, 4^{\prime}\right), 7.36$ (d, 1H, H-5'), 7.17 (d, 2H, H-2,6), 7.14 (d, 2H, H-3,5) ppm.

[Zn(NO $\left.\left.\mathbf{N O}_{2}\right)_{2}\left(\mathbf{L}^{2}\right)\right]$ (4): Yield: $0.58 \mathrm{~g}(32 \%)$. m.p. $191-192^{\circ} \mathrm{C}$. Anal. calc. (\%) for $\mathrm{C}_{12} \mathrm{H}_{11} \mathrm{~N}_{3} \mathrm{O}_{6} \mathrm{SZn}$ : C, 36.89; $\mathrm{H}, 2.84 ; \mathrm{N}, 10.76$. Found (\%): C, 36. 27; H, 2.96; N, 10.25. $\Lambda_{\mathrm{m}}\left(\mathrm{CH}_{3} \mathrm{CN}\right): 3 \Omega^{-1}$ $\mathrm{cm}^{2} \mathrm{~mol}^{-1}$. IR $\left(\mathrm{KBr}, \mathrm{cm}^{-1}\right): 1614 \mathrm{~V}_{\text {asym }}(\mathrm{C}(\mathrm{H})=\mathrm{N})$ imine; $849 \mathrm{v}(\mathrm{C}-$ $\mathrm{S}-\mathrm{C})$ thiophene; $1518,1384 v\left(\mathrm{NO}_{3}\right) .{ }^{1} \mathrm{H} \mathrm{NMR}\left(\mathrm{CDCl}_{3}\right): \delta 8.56$ (s, 1H, H-7), 7.48 (d, 1H, H-3'), 7.45 (d, 1H, H-5'), 7.18 (b, $1 \mathrm{H}, \mathrm{H}-4^{\prime}$ ) , 7.13 (dd, 2H, H-3,5), 7.11 (dd, 2H, H-2,6), 2.35 (s, $\left.3 \mathrm{H}, \mathrm{CH}_{3}\right) \mathrm{ppm}$. 
$\left[\mathbf{Z n}\left(\mathrm{NO}_{3}\right)_{2}\left(\mathbf{L}^{3}\right)\right](\mathbf{5})$ : Yield $0.68 \mathrm{~g}(36 \%)$. m.p. $70-71^{\circ} \mathrm{C}$. Anal. calc. (\%) for $\mathrm{C}_{11} \mathrm{H}_{8} \mathrm{~N}_{3} \mathrm{O}_{6} \mathrm{SZnCl}$ : C, 32.14; $\mathrm{H}, 1.96 ; \mathrm{N}$, 10.22. Found (\%): C, 33.30; H, 2.10; N, 10.90. $\Lambda_{\mathrm{m}}\left(\mathrm{CH}_{3} \mathrm{CN}\right)$ : $4 \Omega^{-1} \mathrm{~cm}^{2} \mathrm{~mol}^{-1}$. IR $\left(\mathrm{KBr}, \mathrm{cm}^{-1}\right): v_{\text {asym }}(\mathrm{C}(\mathrm{H})=\mathrm{N})$ imine; $822 \mathrm{v}(\mathrm{C}-$ $\mathrm{S}-\mathrm{C})$ thiophene; $1520,1384 v\left(\mathrm{NO}_{3}\right) .{ }^{1} \mathrm{H}$ NMR $\left(\mathrm{CDCl}_{3}\right): \delta 8.55$ (s, 1H, H-7), 7.55 (m, 2H, H-3', $\left.4^{\prime}\right), 7.36$ (d, 1H, H-5'), 7.17 (dd, 2H, H-2,6), 7.15 (dd, 2H, H-3,5) ppm.

Antidiabetic activity: Antidiabetic activity of the compounds $\mathbf{1 - 5}$ was screened by $\alpha$-glucosidase inhibitory assay and performed according to Kumar et al. [19]. The experimental procedure is briefly described below as reported earlier [20] . In a microplate, $25 \mu \mathrm{L}$ of sample solution in water $(1 \mathrm{mg} / \mathrm{mL})$ and $25 \mu \mathrm{L}$ of enzyme were added in the well and the solution was mixed gently and incubated at $37 \pm 1{ }^{\circ} \mathrm{C}$ for $10 \mathrm{~min}$. Afterwards, $25 \mu \mathrm{L}$ of the substrate ( $p$-nitrophenyl $\alpha$-D glucopyranoside in $0.5 \mathrm{mM}$ concentration in the buffer, $\mathrm{pH} 6.8$ ) was added in the mixture and incubated again at $37^{\circ} \mathrm{C}$ for $30 \mathrm{~min}$. The reaction was terminated by adding $100 \mu \mathrm{L}$ of $0.2 \mathrm{M}$ sodium carbonate solution. Amount of $p$-nitrophenol released from the substrate was quantified on a UV-visible spectrophotometer at $405 \mathrm{~nm}$ (Multiskan ${ }^{\mathrm{TM}}$ GO Spectrophotometer, ThermoFisher, Finland). Inhibition concentration $\left(\mathrm{IC}_{50}\right)$ of enzyme activity was also calculated by following the same enzyme assay. Appropriate controls were used for each sample and all the analysis were performed in triplicate.

\section{RESULTS AND DISCUSSION}

In a suitable one-pot reaction, a systematic series of five zinc complexes (1-5) with the general stoichiometry $\mathrm{ZnX}_{2} \mathrm{~L}^{1-3}$ (where $\mathrm{X}=\mathrm{Cl}^{-}$or $\mathrm{NO}_{3}{ }^{-}$and $\mathrm{L}$ is a various substituted Schiff base ligands, viz. (E)-N-(thiophen-2-ylmethylene)aniline, $(E)$ 4-methyl-N-(thiophen-2-ylmethylene) aniline and $(E)-4-$ chloro-N-(thiophen-2-ylmethylene)aniline] were synthesized. In alcohol, one equivalent of $\mathrm{MX}_{2}$ reacts rapidly with one equivalent of L (generated in situ from thiophene-2-carboxaldehyde and a substituted aniline) to give a yellow precipitate which proved to be Schiff base metal complexes (Scheme-I) analogous to that reported for palladium analogues [15].The general stoichiometry of $\left[\mathrm{MX}_{2} \mathrm{~L}^{1-3}\right]$ complexes have been corro- borated by the micro-analytical results, which clearly evidenced the formation of 1:1 adducts between the bidentate S,N-donors $\mathrm{L}^{1-3}$ and $\mathrm{MX}_{2}$. In all cases, air stable pale yellow solids were obtained in moderate to good yields and these complexes behave as non-electrolytes in acetonitrile solution. Complexes $\mathbf{1 - 5}$ are soluble in water, alcohol, acetonitrile, DMSO and DMF.

IR spectra: The infrared spectra of complexes $\mathbf{1 - 5}$ are very similar. The entire complexes spectrum compared with the literature value. The complexes display a moderately intense IR band in the region1620-1590 $\mathrm{cm}^{-1}$, which is assigned to be $v_{\text {asym }}(C(H)=N)$ stretching frequency of the coordinated Schiff base ligands [21]. In addition, well resolved sharp bands of variable intensity observed in the regions $872-856,846$ and $730-714 \mathrm{~cm}^{-1}$ are assigned to the coordinated sulphur of the thiophene ring [15,22]. The complexes $\mathbf{4}$ and $\mathbf{5}$ also showed a very strong band at approximately $1384 \mathrm{~cm}^{-1}$ which is indicative of the simultaneous presence of coordinated nitrates [23]. In addition, the solid state spectrum of complexes $\mathbf{4}$ and 5 displayed bands at 1513-1381 $\mathrm{cm}^{-1}$, suggesting bidentate chelating nitrate groups [21,24].
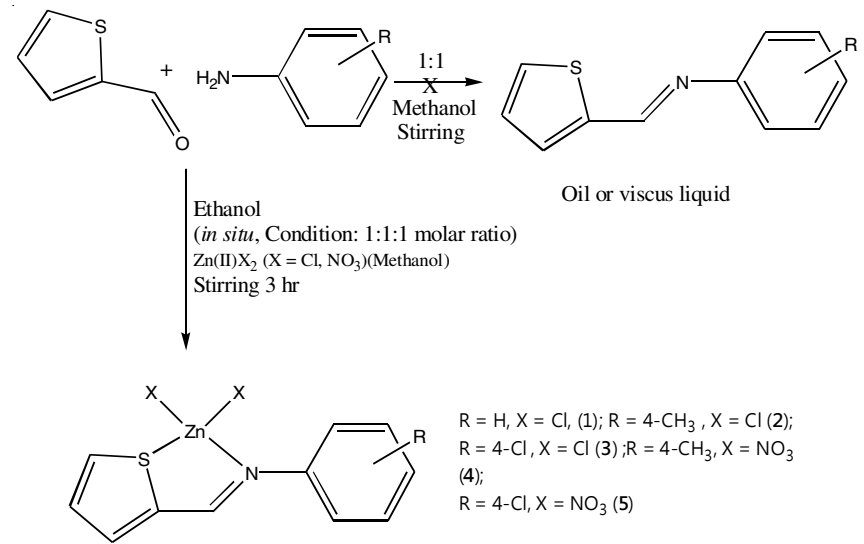

Scheme-I: Reaction scheme for the synthesis of $\left[\mathrm{Zn}(\mathrm{X})_{2}\left(\mathrm{~L}^{\mathrm{n}}\right)\right]$ complexes

UV-visible and fluorescence spectra: The UV-visible and fluorescence properties of complexes 1-5 are summarized in Table-1. The absorption spectra of all the complexes were
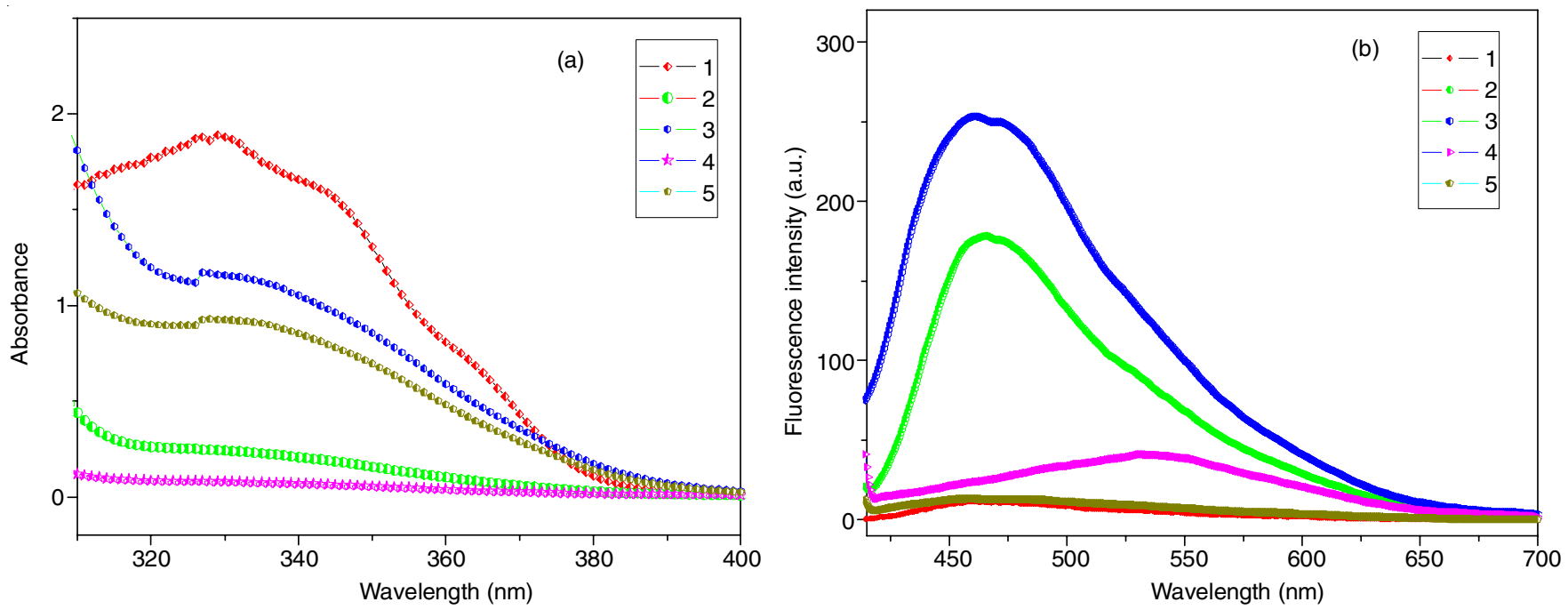

Fig. 2. (a) UV-visible spectra of compounds 1-5 in acetonitrile solution (concentration $\sim 10^{-5} \mathrm{M}$ ). (b) Fluorescence spectra of compounds 1-5 in acetonitrile solution(concentration $\sim 10^{-5} \mathrm{M}$ ) obtained by excitation at the respective absorption maxima 
recorded in the range $300-400 \mathrm{~nm}$ in acetonitrile solutions at concentrations of about $10^{-5} \mathrm{M}$. The electronic spectra exhibit a coalescence absorption in the range of 330 to $350 \mathrm{~nm}$ (Fig. 2a). The origin of the band could not be assigned unambiguously due to the non-availability of data for the free ligands [21]. The steady-state fluorescence studies have been employed as independent evidence of complexation. In acetonitrile solution, the complexes have broad emission bands at $\lambda_{\mathrm{em}}=460$ $\mathrm{nm}$ within the wavelength range of 400-700 $\mathrm{nm}$, when they are excited at their respective absorption maxima (Fig. 2b) at room temperature. Nevertheless, these emissions could not be confined as metal-to-ligand charge transfer (MLCT) or ligandto-metal charge transfer (LMCT) as zinc(II) ion, with a $d^{10}$ configuration, is not easily oxidized or reduced [25]. The emissions are suggested to be intra-ligand (IL) $\left(\pi-\pi^{*}\right)$ emission and the $\mathrm{Zn}$ complexes showed very low fluorescence quantum yields [26] (Table-1).

\begin{tabular}{cccc}
\multicolumn{4}{c}{ TABLE-1 } \\
\multicolumn{4}{c}{$\begin{array}{c}\text { PHOTOPHSICAL DATA FOR COMPLEXES 1-5 } \\
\text { IN ACETONITRILE SOLUTION }\end{array}$} \\
\hline \multirow{2}{*}{ Complexes } & $\begin{array}{c}\text { Electronic spectroscopic } \\
\text { data } \lambda_{\max }(\mathrm{nm})\end{array}$ & \multicolumn{2}{c}{ Photoluminescence data } \\
\cline { 3 - 4 } & 330 & $\lambda_{\mathrm{em}}(\mathrm{nm})$ & $\phi_{\mathrm{F}}$ \\
\hline $\mathbf{1}$ & 337 & 467 & 0.14 \\
$\mathbf{2}$ & 336 & 465 & 0.24 \\
$\mathbf{3}$ & 340 & 467 & 0.16 \\
$\mathbf{4}$ & 335 & 536 & 0.38 \\
$\mathbf{5}$ & & 464 & 0.10 \\
\hline
\end{tabular}

${ }^{1}$ H NMR spectra: The ${ }^{1} \mathrm{H}$ NMR spectra of the complexes 1-5 were recorded in $\mathrm{CDCl}_{3}$ solution. The complexes displayed the expected signals and confirmed the presence of the ligand skeleton in the respective complexes. In the spectra, coupling constants could not be established with certainty owing to the broad unresolved nature of the signals [21]. The change of ligands coordination to zinc(II) upon ${ }^{1} \mathrm{H}$ NMR chemical shifts could not be confined in the absence of NMR data for the free ligands (prepared in situ). The ${ }^{1} \mathrm{H} N \mathrm{MR}$ spectra of all the complexes shows a singlet peak at around 8.7-8.9 ppm which may be assigned to $\mathrm{HC}=\mathrm{N}$ protons. A singlet peak appeared around 2.3 ppm is due to methyl group in complexes $\mathbf{2}$ and $\mathbf{4}$. The multiplets observed at around 6.7-8.3 ppm for all the complexes are due to protons of the aromatic ring [15].

Proposed structure of the complexes: Coordination number four is by far the most common structural feature in the chemistry of zinc(II) complexes. The two limiting configurations generally observed for $\mathrm{Zn}$ (II) complexes are tetrahedral and square planar [27] and only a few can be classified as (distorted) square planar $[28,29]$. Efforts for getting single crystals suitable for X-ray crystal structure analysis could not be achieved. However, from the spectroscopic data analysis of the similar ligand system reported earlier [2,15], the ligands are proposed to be bidentate nature of coordination. In the present paper, zinc (II) complexes resulted from Schiff base ligands, $\mathrm{L}^{1-3}$ with $\mathrm{Zn}(\mathrm{II}) \mathrm{Cl}_{2}$ and $\mathrm{Zn}\left(\mathrm{NO}_{3}\right)_{2}$ were characterized by elemental analyses, molar conductance, UV-visible, IR and ${ }^{1} \mathrm{H}$ NMR spectroscopy. From the IR spectra, it is indicated that $\mathrm{L}^{1-3}$ behaves as a bidentate ligand coordination to the metal ions viz. azomethine- $\mathrm{N}$ and thiophene-S [2,30,31]. In addition, the IR spectra of zinc complexes with $\mathrm{Zn}\left(\mathrm{NO}_{3}\right)_{2}$ also showed bidentate nature of coordination of nitrate ion to the metal atom $[21,23]$. From the molar conductance data, it was found that $\mathrm{Zn}(\mathrm{II})$ chelate may be considered as 1:1 (L:M) composition with the ligands [21]. The ${ }^{1} \mathrm{H}$ NMR spectra of the complexes are in good agreement with the formation of the expected compounds [31]. From the above spectroscopic observations and on the basis of the related structures of zinc(II) and mercury(II) complexes reported earlier [26,27,33,34], the structure of the complexes can be suggested to have tetrahedral geometry for complexes 1-3 and octahedral geometry for complexes $\mathbf{4}$ and $\mathbf{5}$ (Fig. 1b).

Antidiabetic activity: The antidiabetic activity of the synthetic complexes were screened using $\alpha$-glucosidase enzyme and found that only complex 1 showed inhibition more than $50 \%$ of $\alpha$-glucosidase activity (Fig. 3). Since complex 1 showed significant activity as compared to other complexes, $\mathrm{IC}_{50}$ for only complex 1 was calculated and compared with the standard drug, acarbose. The $\mathrm{IC}_{50}(\mu \mathrm{g} / \mathrm{mL})$ values for the complex 1 along with the standard compound acarbose are listed in Table-2. It is clear from Table- 2 that complex $\mathbf{1}$ exhibited $\mathrm{IC}_{50}$ values at $24.45 \mu \mathrm{g} / \mathrm{mL}$ as compared with the standard drug, acarbose which exhibits $\mathrm{IC}_{50}$ value at $15.55 \mu \mathrm{g} / \mathrm{mL}$. Complex 1 showed effective antidiabetic activity among the screened complexes. The results of antidiabetic activity of the complexes could not be compared with that of the related zinc complexes due to different methodology of antidiabetic assay adopted $[16,17]$. However, the antidiabetic activity of this complex was compared with the organotin(IV) compounds of azo-carboxylates [20,35] and standard drug acarbose and was found to be lower activity.

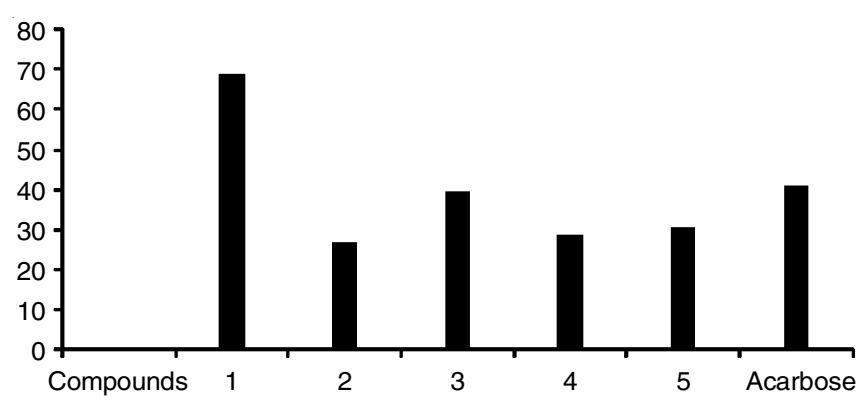

Fig. 3. Pictorial diagram for antidiabetic activity (\% inhibition) of zinc compounds 1-5 along with standard drug acarbose

TABLE-2

ANTIDIABETIC ACTIVITY OF ZINC COMPLEXES 1-5

\begin{tabular}{ccc}
\hline Compounds & $\mathrm{IC}_{50}(\mu \mathrm{g} / \mathrm{mL})$ & $\mathrm{SD}$ \\
\hline $\mathbf{1}$ & 24.45 & 4.60 \\
Acarbose & 15.55 & 0.43 \\
\hline
\end{tabular}

\section{Conclusion}

The syntheses of five water soluble zinc complexes with substituted (E)-N-(thiophen-2-ylmethylene)anilines were successfully accomplished. These complexes have been characterized by physio-chemical data and spectroscopic techniques such as UV-visible, fluorescence, IR and ${ }^{1} \mathrm{H}$ NMR. In all cases, air stable pale yellow solids were obtained in moderate to good yields and these complexes behave as non-electrolytes in acetonitrile solution. UV-visible, fluorescence and IR spectral studies indicate that the ligands $\left(\mathrm{L}^{1-3}\right)$ are coordinated to the metal complexes. 
The emission spectra of all the complexes shows $\pi-\pi^{*}$ (intraligand) transition. The study of the complexes suggested to have four and six coordinate geometry around zinc atom. Complexes 1-3 are four coordinated tetrahedral structures while complexes $\mathbf{4}$ and $\mathbf{5}$ are six coordinated octahedral structures. The antidiabetic activity of the complexes was investigated against $\alpha$-glucosidase enzyme and compound 1 was found to exhibit effective activity.

\section{ACKNOWLEDGEMENTS}

The authors thank Department of Chemistry, National Institute of Technology Agartala for research facilities and IISc, Bangalore for providing NMR spectra. The authors also acknowledge to Department of Biotechnology, Government of India (Grant no. BT/32/NE/2011) for Biotech Hub in the Department of Forestry, North Eastern Regional Institute of Science and Technology, Nirjuli, India.

\section{REFERENCES}

1. R.C. Maurya, D.D. Mishra, S. Jain and M. Jaiswal, Synth. React. Inorg. Met.-Org. Chem., 23, 1335 (1993);

https://doi.org/10.1080/15533179308016690.

2. A. Hatzidimitriou and C.A. Bolos, Polyhedron, 17, 1779 (1998); https://doi.org/10.1016/S0277-5387(97)00438-5.

3. J.M. Tercero, A. Matilla, M.A. Sanjuán, C.F. Moreno, J.D. Martín and J.A. Walmsley, Inorg. Chim. Acta, 342, 77 (2003); https://doi.org/10.1016/S0020-1693(02)01071-X.

4. N.M. Milovic, L.-M. Dutca and N.M. Kostic, Inorg. Chem., 42, 4036 (2003); https://doi.org/10.1021/ic026280w.;

5. J.G. Tojal, J.L. Pizarro, A. Garcia-Orad, A.R. Perez-Sanz, M. Ugalde, A.A. Diaz, J.L. Serra, M.I. Arriortua and T. Rojo, J. Inorg. Biochem., 86, 627 (2001); https://doi.org/10.1016/S0162-0134(01)00210-0.

6. A.S. Demir, O. Reis and M. Emrullahoglu, Tetrahedron, 58, 8055 (2002); https://doi.org/10.1016/S0040-4020(02)01001-3.

7. C.-Y. Wu, L.-H. Chen, W.-S. Hwang, H.-S. Chen and C.-H. Hung, J. Organomet. Chem., 689, 2192 (2004); https://doi.org/10.1016/j.jorganchem.2004.04.004.

8. M. da Cunha Belo, J. Electrochem. Soc., 124, 1317 (1977); https://doi.org/10.1149/1.2133616.

9. H.L. Singh, S. Varshney and A.K. Varshney, Appl. Organomet. Chem., 13, 637 (1999); https://doi.org/10.1002/(SICI)1099-0739(199909)13:9<637::AIDAOC $919>3.0 . \mathrm{CO} ; 2-\mathrm{K}$

10. M. Idren, M. Siddique, S.D. Patil, A.G. Joshi and A.W. Raut, Orient. J. Chem., 17, 131 (2001).

11. N. Sar and P.G. Urkan, Z. Naturforsch., 59b, 692 (2004).

12. K.S. Siddiqi, R.I. Kureshy, N.H. Khan, S. Tabassum and S. Zaidi, Inorg. Chim. Acta, 151, 95 (1988); https://doi.org/10.1016/S0020-1693(00)91888-7.

13. D.A. Laidler and D.J. Milner, J. Organomet. Chem., 270, 121 (1984); https://doi.org/10.1016/0022-328X(84)80341-1.

14. E. Pontiki, D. Hadjipavlou-litina and A.T. Chaviara, J. Enzyme Inhib. Med. Chem., 23, 1011 (2008); https://doi.org/10.1080/14756360701841251.
15. J. Wiedermann, K. Mereiter and K. Kirchner, J. Mol. Catal. Chem., 257, 67 (2006); https://doi.org/10.1016/j.molcata.2006.04.009.

16. M.E. Lopez-Viseras, B. Fernandez, S. Hilfiker, C.S. Gonzalez, J.L. Gonzalez, A.J. Calahorro, E. Colacio and A. Rodriguez-Dieguez, J. Inorg. Biochem., 131, 64 (2014); https://doi.org/10.1016/j.jinorgbio.2013.10.019.

17. J. Vanco, J. Marek, Z. Trávnícek, E. Racanská, J. Muselík and O. Svajlenová, J. Inorg. Biochem., 102, 595 (2008); https://doi.org/10.1016/j.jinorgbio.2007.10.003.

18. N.S. Moyon and S. Mitra, J. Phys. Chem. B, 115, 10163 (2011); https://doi.org/10.1021/jp204424w.

19. D. Kumar, H. Kumar, J.R. Vedasiromoni and B.C. Pal, Phytochem. Anal., 23, 421 (2012); https://doi.org/10.1002/pca.1375.

20. M. Roy, S. Roy, K.S. Singh, J. Kalita and S.S. Singh, Inorg. Chim. Acta, 439, 164 (2016); https://doi.org/10.1016/i.ica.2015.10.012.

21. T.S. Basu Baul, S. Kundu, S. Mitra, H. Höpfl, E.R.T. Tiekink and A. Linden, Dalton Trans., 42, 1905 (2013); https://doi.org/10.1039/C2DT32283H.

22. R.C. Maurya and P. Patel, Spectrosc. Lett., 32, 213 (1999); https://doi.org/10.1080/00387019909349979.

23. K. Nakamoto, Infrared and Raman Spectra of Inorganic \& Coordination Compounds, Wiley, New York (1986).

24. G.J. Kleywegt, W.G.R. Wiesmeijer, G.J. Van Driel, W.L. Driessen, J. Reedijk and J.H. Noordik, J. Chem. Soc., Dalton Trans., 2177 (1985); http://dx.doi.org/10.1039/DT9850002177.

25. C.C. Ji, L. Qin, Y.Z. Li, Z.J. Guo and H.G. Zheng, Cryst. Growth Des., 11, 480 (2011); https://doi.org/10.1021/cg101261f.

26. C. Seward, J. Chan, D. Song and S.N. Wang, Inorg. Chem., 42, 1112 (2003); https://doi.org/10.1021/ic020480q.

27. M. Melnik, K. Gyoryova, J. Skorsepa and C.E. Holloway, J. Coord. Chem., 35, 179 (1995); https://doi.org/10.1080/00958979508024038.

28. U. Simonis, F.A. Walker, P.L. Lee, B.J. Hanquet, D.J. Meyerhoff and W.R. Scheidt, J. Am. Chem. Soc., 109, 2659 (1987); https://doi.org/10.1021/ja00243a018.

29. W.R. Scheidt, J.U. Mondal, C.W. Eigenbrot, A. Adler, L.J. Radonovich and J.L. Hoard, Inorg. Chem., 25, 795 (1986); https://doi.org/10.1021/ic00226a014.

30. M.C. Sharaby, Spectrochim. Acta A Mol. Biomol. Spectrosc., 66, 1271 (2007); https://doi.org/10.1016/j.saa.2006.05.030

31. A.K. Boudalis, V. Nastopoulos, S.P. Perlepes, C.P. Raptopoulou and A. Terzis, Transition Met. Chem., 26, 276 (2001); https://doi.org/10.1023/A:1007185119324.

32. T.S. Basu Baul, S. Kundu, P. Singh, S. Shaveta and M.F.C. Guedes da Silva, Dalton Trans., 44, 2359 (2015); https://doi.org/10.1039/C4DT03151B.

33. T.S. Basu Baul, S. Kundu, A. Linden, N. Raviprakash, S.K. Manna and M.F.C. Guedes da Silva, Dalton Trans., 43, 1191 (2014); https://doi.org/10.1039/C3DT52062E.;

34. I. Tasuku, K. Masako and I. Haruko, Bull. Chem. Soc. Jpn., 57, 2634 (1984); https://doi.org/10.1246/bcsj.57.2634.

35. M. Roy, S. Roy, K.S. Singh, J. Kalita and S.S. Singh, New J. Chem., 40, 1471 (2016); https://doi.org/10.1039/C5NJ02637G 